\title{
FAMILJEUNDERVISNINGSMODELLEN FÖR VÅRD AV UNGA LAGÖVERTRÄDARE
}

\author{
Av Sten Rönnberg, Stockholm
}

Achievement Place kallas ett behandlingsprogram i hemliknande miljö, som började utvecklas i Lawrence, Kansas, år 1967. Det är avsett för ungdomar i åldern 12-16 år. Dessa ungdomar har mestadels dömts till skyddstillsyn och har i flesta fall getts beteckningen »delinquent« eller »predelinquent«.

Det första Achievement Place upprättades av de lokala myndigheterna och utvecklades med hjälp av utbildade beteendeterapeuter från Kansasuniversitetet och med välvilligt stöd från flera fonder för brottsbekämpning till att tjäna som en modell för behandling i större skala. I ett vanligt enfamiljshus hodde ett »föräldrapar«, som var doktorander vid Kansasuniversitetet, tillsammans med 6-8 pojkar, som hade remitterats för behandling av ungdomsdomstolen i distriktet. Det första Achievement Place följdes snart av flera, så att det nu finns mer än 150 sådana behandlingshem i funktion i USA för antingen pojkar eller flickor. Behandlingshemmen finns i ett flertal stater och föräldraparen är organiserade i en gemensam organisation: National Teaching Family Association.

Föräldraparen är vanligtvis i 30-årsåldern, men det finns också par där någon av eller båda föräldrarna är i 22-23-årsåldern eller över 60 år. De flesta som arbetar som vårdföräldrar har en Bachelor of Art (motsvarande fil.kand.) och försöker kvalificera sig för en Master of Art (fördjupade universitetsstudier $\mathrm{i}$ ett ämne, motsvarande något mer än G-kurs vid svenska universitet). Man får då poäng i sin Master-utbildning av att arbeta som vårdföräldrar och ges dessutom möjligheter att göra en vetenskaplig uppsats inom sitt arbete.

Arbetet för vårdföräldrarna består i praktiskt taget 24 timmars jour i fem dagar i veckan. Det finns alltså en avlösare till varje Achievement Place som kan ta över två dagar i veckan. Formellt har man inte mer än 40 timmars arbetsvecka, men reellt innebär systemet, att vårdföräldrarna kan nödgas ställa upp på fritiden, på natten, när som helst, när det behövs.

De rutiner man har vid varje sådant Achievement Place liknar den man har i många amerikanska familjer: Upp klockan 7, sedan dusch, påklädning, iväg till skolan, eftermiddagsmål, läxor, fritidssysselsättningar, kvällsmål, gemensam samling, i säng klockan 21.30. Individuella program görs för varje elev i behandlingshemmet.

Det har publicerats mer än ett 50-tal vetenskapliga undersökningar som rör Achievement Place. En stor del av dessa har publicerats i tidskriften Journal of Applied Behavior Analysis. 
Achievement Place utmärks framför allt av följande: Samhällsinriktning, teckenekonomi, modifiering av skolbeteenden genom åtgärder $\mathrm{i}$ hemmet, fortgående revidering och förfining av arbetsmodellen (Phillips et al. 1972, Hoefler \& Bornstein 1975). Var och en av dessa huvudingredienser beskrivs närmare nedan.

\section{Samhällsinriktning}

För varje behandlingshem finns en styrelse med representanter för den lokala befolkningen och myndigheterna. Styrelsen samarbetar nära med föräldraparet i behandlingshemmet, med de lokala skolmyndigheterna, ungdomsdomstolen i distriktet, de lokala kyrkliga sammanslutningarna och andra intresserade. Styrelsen väljer behandlingsmål för hemmet och utvärderar huruvida programmet uppnått de ställda målen. En särskild kommitté bestående av föräldraparet, en representant för skolan, en person från ungdomsdomstolen och en socialarbetare gör urvalet av de ungdomar som skall få komma till hemmet.

Varje behandlingshem är avsett att tjäna ett visst område. Ungdomarna får gå kvar i sin gamla skola, tillåts täta besök i sina naturliga hem och får också besöka gamla kamrater. Föräldraparet hjälper ungdomarna med kontakter i olika former utanför behandlingshemmet.

Behandlingshemmet finansieras till övervägande del med allmänna medel. Kostnaderna ligger på ungefär hälften av de motsvarande vård av ungdomar i delstatliga institutioner kostar. Etableringskostnaderna per sängplats var 1971 ungefär 6.000-8.000 dollar jämfört med 20.000-30.000 dollar i vanliga delstatliga institutioner, och 4.000-5.000 dollar i driftskostnad per yngling och år jämfört med 8.000-10.000 dollar i många vanliga delstatliga institutioner (Phillips et al. 1972).

\section{Teckenekonomi}

I varje behandlingshem finns ett system för utdelande av poäng för fullgjorda handlingar. Detta poängsystem som brukar kallas teckenekonomi är avsett som ett hjälpmedel att lära enkla regler och handlingar som förekommer i en normalfamilj. Systemet är upplagt för att ge maximal information och återkoppling till ungdomarna under första tiden de vistas $\mathrm{i}$ behandlingshemmet. Det överges sedan successivt och ersätts med mera naturliga reaktioner på beteendet.

Varje elev i ett behandlingshem bär på sig ett $7,5 \mathrm{~cm} \times 10 \mathrm{~cm}$ stort kort, på vilket han/hon adderar poäng som han förvärvat och drar ifrån poäng som han förlorar under dagen. Som i alla väl upplagda teckenekonomiprogram, så är det förhållandevis lätt att skaffa sig poäng. Man kan få poäng för att titta på nyheterna i TV eller läsa en dagstidning, för att städa och hålla snyggt i sitt rum, för att hålla sig ren och snygg själv, för att läsa böcker, 
hjälpa till i hushållet, osv. Men det är också lätt hänt för dessa ungdomar att någon gång bli av med poäng. Det betyder förlust av poäng att tala aggressivt, att glömma att tvätta händerna före måltiderna, att inte lyda regler, att argumentera häftigt mot, att komma sent osv.

Varje elevs poäng räknas samman varje dag för varje beteende och sätts upp på en anslagstavla. På samma anslagstavla står vad man kan få för de poäng man har under den aktuella veckan. Man kan byta ut poängen mot att åka cykel ett tag, titta på TV, mellanmål, deltagande i spel, åka ner på stan, stanna uppe sent, komma hem sent efter skolan osv.

»Priset« $\mathrm{i}$ poäng för varje handling bestäms i huvudsak av föräldraparet, men i nära överläggning med alla invånarna $\mathrm{i}$ behandlingshemmet.

\section{Modifiering av grundläggande beteendemönster}

De pojkar som får börja i Achievement Place har i allmänhet en bakgrund som karakteriseras av torftiga hemförhållanden. De har själva i de flesta fall begått åtskilliga mindre brott, har misslyckats i skolan och of ta skolkat från den. De har ofta beskrivits som aggressiva och ovårdade. Åtskilliga, för mänsklig samlevnad väsentliga, grundläggande beteendemönster eller samlevnadsfärdigheter saknades hos ungdomarna, då de först kom till Achievement Place.

Föräldraparet i varje Achievement Place skall fungera som en god modell för samlevnad. Också kamraterna skall bidra till en miljö, där ynglingen finner många exempel på god samlevnadsfärdighet. Pojkarnas adekvata sociala handlande vidmaktshålls sedan till en början genom teckenekonomisystemet. På så sätt har man kunnat modifiera sådana beteendemönster som att förstöra materiel, djurplågeri, slag och hot mot personer (se t ex Phillips 1968). I stället för dessa av de flesta ansedda mindre adekvata handlingar, har man byggt upp mera socialt acceptabla beteenden.

\section{Experimentell metodik}

Beteendeterapeuter vill gärna se sig som mera styrda av data hämtade från den iakttagbara verkligheten än av teorier. Mätning och experimentell metodik är viktiga för att kartlägga verkligheten och finna orsakssamband mellan dess olika delar. Inom Achievement Place har en mängd data om ungdomarna insamlats. Man har gjort en mängd experiment med enskilda individer, vanligen efter en s k ABAB-design, där A står för en period då man bara observerar och $B$ för en period då man vidtar en åtgärd som man vill studera effekten av (Hersen \& Barlow 1976, Nordlund \& Rönnberg 1976).

\section{Modifiering av skolbeteenden genom åtgärder $i$ hemmet}

En stor del av ungdomarna i Achievement Place har problem i skolan. Dessa har åtgärdats i skolan med direkt samarbete med lärare och annan personal 
på skolan i de flesta fall. Som regel har dock också ett program för arbete med problem i hemmet assisterat skolprogrammet och i många fall varit behandlingens viktigaste ingrediens.

\section{Fortgående revidering och förfining av arbetsmodellen}

Achievement Place är ingen till alla delar färdig arbetsmodell. Dess innehåll förändras successivt med nya erfarenheter. Nedan anges några områden, där viktiga förändringar skett i programmet sedan begynnelsen år 1967.

Prissättningen i teckenekonomisystemet har förändrats så, att varje elev numera bör ha minst 1.000 poäng mer än han förlorar varje dag för att få till fullo ta del av de privilegier som ges dagen därpå.

Utbytet av intjänade poäng mot privilegier gjordes till en början en gång i veckan. Numera sker detta efter varje timma för de senast intagna. Sedan övergår man successivt till utbyte efter en dag och oftast först efter 6-8 veckor till utbyte en gång i veckan.

Vissa privilegier, som är svåra att ge en och en, ges nu i paket, t ex använda telefon, radio, lekrummet eller att gå ut.

Kännetecknande för arbetet under senare år är också att man alltmer betonar de personliga relationernas betydelse. Man väljer vårdföräldrar mycket noga och försöker därvid få med särskilt sådana som har förmåga till inlevelse med ungdomarna, kan fungera som goda exempel, kan uppmuntra ungdomarna på rätt sätt, har humor, osv. Studier pågår $\mathrm{f} n$ där man försöker mera precist notera vilka relationsfärdigheter som har störst betydelse för lyckad behandling.

Man har ett väl utprövat system för vidareutbildning av vårdföräldrar. Omedelbart som ett par har anställts ges de en veckas intensiv träning av erfarna vårdföräldrar. Två månader senare ges en ny träningskurs. Efter fem månader hålls en veckas mer avancerad träning för vårdföräldrarna, då också personer från den vetenskapliga ledningen av hela Achievement Place vid Kansasuniversitetet är med. Under hela anställningstiden för vårdföräldrarna hålls också studiedagar, vanligen en varannan månad.

Achievement Place har med åren blivit mindre och mindre direktstyrt av föräldraparen och andra vuxna och mer och mer styrt av ungdomarna själva. Till en del hör detta ihop med den utveckling inom beteendeterapin som mer och mer övertygat om de självreglerande processernas betydelse (se t ex Bandura 1977, Rönnberg 1977). Det är viktigt, att individen är maximalt med på en förändring och aktivt deltar i den, observerar sina egna handlingar och själv lär sig reglera yttre och inre konsekvenser på sina handlingar.

\section{Effekter av Achievement Place}

I huvuddelen av de undersökningar som finns publicerade rörande Achievement Place finns resultat redovisade. De är alla positiva på så sätt, att 
önskad beteendeförändring helt eller delvis har skett. Detta är kännetecknande för tillämpad experimentell beteendeanalys: Man ändrar programmet tills man fått önskade effekter. Intressantare än dessa individstudier är därför kanske den allmänna evaluering av effekterna för Achievement Place, som gjorts. Det finns hittills bara en sådan helt färdig undersökning publicerad (Phillips et al. 1973).

Två år efter avslutad behandling hade $19 \%(\mathrm{n}=16)$ av ungdomarna som gått i Achievement Place åkt in på institution igen, medan motsvarande siffra för en kontrollgrupp låg på $54 \%$. Tredje terminen efter behandling så gick $90 \%(n=16)$ av dem som gått i Achievement Place kvar i skolan, medan motsvarande siffror för kontrollgrupper var $9 \%$ respektive $37 \%$. Ungdomarna från Achievement Place klarade sig också betydligt bättre i skolan.

I en ännu inte publicerad undersökning (Kirigin et al. 1980) redovisar man resultat som tyder på att de positiva effekterna av behandlingen till stor del försvinner efter några år, när de unga återgår till sin vanliga miljö. Man är därför numera alltmer inriktad på att träna sådana färdigheter som ger långtidseffekter i den naturliga miljö som ungdomarna kan tänkas möta sedan de slutat vid Achievement Place.

\section{Avslutande kommentarer}

Systematisk undervisning av unga lagöverträdare i hemliknande miljö liknande vad som gjorts i USA inom Achievement Place borde också vara möjlig att pröva i de nordiska länderna. Programmet är tillräckligt intressant för att kräva noggrant studium av dem som vill försöka göra något åt ungdomskriminaliteten hos oss. Det har en i sammanhanget unik forskningsförankring och utvärderingsmetodik förknippad med sig, så att det är möjligt att uttala sig om programmets värde. Dess positiva erfarenheter bör också komma nordisk ungdomsvård till godo. Studium av Achievement Place bör också kunna verka befruktande på liknande program i Sverige, t ex Hasselapedagogiken.

\section{Sten Rönnberg.}

\section{REFERENSER}

Bandura, A. Social learning theory. Englewood Cliffs, N. J.: Prentice Hall, 1977.

Center for Studies of Crime and Delinquency. Achievement Place: Phase II. Volume 2. Final Report for Grant No. MH 20030. Bethesda, Maryland: NIMH. 1974.

Hersen, M. Token economies in institutional settings. Historical, political, deprivation, ethical, and generalization issues. The Journal of Nervous and Mental Disease, 1976, 162, 206-211.

Hersen, M. \& D. H. Barlow. Single case experimental designs. Strategies for studying behaviour change. New York: Pergamon, 1976. 
Hoefler, S. A. \& P. H. Borstein. Achievement Place: An evaluative review. Criminal Justice and Behavior, 1975, 2, 146-168.

Kirigin, K. A., Braukmann, J. Atwater \& M. M. Wolf. An evaluation of the Achievement Place Teaching-Family Model of group home treatment for delinquency youths. Journal of Applied Behavior Analysis, 1980, 13, in press.

Kirigin, K. A., M. M. Wolff, C. J. Braumann, D. L. Fixen \& E. L. Phillips. Achievement Place: A preliminary outcome evaluation. In J. S. Stumphauzer (Ed.) Progress in Behavior Therapy with Delinquents. Springfield, Ill.: Charles C. Thomas, 1979, pp. 118-145.

Nordlund, O. \& S. Rönnberg. Group designs and individual designs in psychotherapy research. Research Bulletin from the Institute of Education, University of Stockholm, Volume IV, No. 2, September 1976.

Phillips, E. L. Achicvement Place: token reinforcement procedures in a home-style rehabilitation setting for "pre-delinquent" boys. Journal of Applied Behavior Analysis, 1968, 1, 213-223.

Phillips, E. L., E. A. Phillips, D. L. Fixen \& M. M. Wolff. Achievement Place. Behavior shaping work for delinquents. Psychology Today, June 1973, 1, $74-79$.

Phillips, E. L., E. A. Phillips, D. L. Fixen \& M. M. Wolff. The teaching-family handbook. Lawrence, Kansas: University of Kansas, 1972.

Rönnberg, S. En introduktion till beteendeterapi. Stockholm: GBM, 1977. 